\title{
Combined spectral karyotyping, comparative genomic hybridization, and in vitro apoptyping of a panel of Burkitt's lymphoma-derived $B$ cell lines reveals an unexpected complexity of chromosomal aberrations and a recurrence of specific abnormalities in chemoresistant cell lines
}

\author{
MARIA B. KARPOVA ${ }^{1,3}$, JACQUELINE SCHOUMANS ${ }^{2}$, ELISABETH BLENNOW ${ }^{2}$, INGEMAR ERNBERG ${ }^{4}$, \\ JAN-INGE HENTER ${ }^{1}$, ALEKSANDR F. SMIRNOV ${ }^{3}$, MAGNUS NORDENSKJÖLD ${ }^{2}$ and BENGT FADEEL ${ }^{5}$ \\ ${ }^{1}$ Childhood Cancer Research Unit, Department of Woman and Child Health, ${ }^{2}$ Department of Molecular Medicine, \\ Center for Molecular Medicine, Karolinska University Hospital, S-171 76 Stockholm, Sweden; ${ }^{3}$ Laboratory of Animal \\ Genetics, Department of Genetics and Breeding, St. Petersburg State University, St. Petersburg 199034, Russia; \\ ${ }^{4}$ Microbiology and Tumor Biology Center, ${ }^{5}$ Division of Molecular Toxicology, Institute of \\ Environmental Medicine, Karolinska Institutet, S-171 77 Stockholm, Sweden
}

Received September 22, 2005; Accepted November 14, 2005

\begin{abstract}
The comprehensive cytogenetic profiles of a panel of 10 Burkitt's lymphoma (BL)-derived B cell lines, designated Akata, BL-28, BL-41, Daudi, DG-75, Mutu I, Mutu III, Namalwa, Rael, and Ramos, respectively, are reported herein. The unique origin of each cell line was established using multiplex quantitative fluorescence polymerase chain reaction (QF-PCR). Spectral karyotyping (SKY) revealed a large number of structural and numerical chromosomal aberrations, many of which had not been previously identified or resolved by conventional G-banding techniques. Notably, whereas all 10 cell lines harbored the hallmark translocation $\mathrm{t}(8 ; 14)(\mathrm{q} 24 ; \mathrm{q} 32)$, no other common structural aberrations were identified, although translocations involving chromosomes 3,13 , and 17 were frequently seen. Moreover, analysis of chromosomal breakpoints by comparative genomic hybridization (CGH) revealed a number of recurring aberrations, such as gain of chromosomes 7 and 20, gains of regions at 2p, 3q, 13q and $16 \mathrm{q}$, and losses at $3 \mathrm{p}, 4 \mathrm{q}$ and $17 \mathrm{p}$. In addition, apoptyping (i.e. determination of in vitro responses to apoptosis stimulation) of the cell lines suggested specific association patterns between karyotypic changes (e.g. translocations involving $17 \mathrm{p}$, and gains of portions of chromosomes 7 and 20) and resistance to the chemotherapeutic agent, etoposide. The current molecular
\end{abstract}

Correspondence to: Dr Bengt Fadeel, Division of Molecular Toxicology, Institute of Environmental Medicine, Nobels väg 13, Karolinska Institutet, S-171 77 Stockholm, Sweden

E-mail: bengt.fadeel@ki.se

Key words: apoptosis, Burkitt's lymphoma, comparative genomic hybridization, spectral karyotyping, quantitative fluorescence polymerase chain reaction cytogenetic characterization of $10 \mathrm{BL}$ cell lines has thus identified several novel sites of rearrangements; moreover, the combined karyotyping and functional assessment (apoptyping) of these cell lines serves to enhance their utility in future studies aimed at gene discovery and gene function.

\section{Introduction}

Burkitt's lymphoma (BL) is a highly aggressive non-Hodgkin's lymphoma (NHL) consisting of endemic, sporadic, and immunodeficiency-associated variants (1). All of these subtypes possess chromosomal rearrangements of the c-myc oncogene, the genetic hallmark of BL that is believed to contribute to lymphomagenesis through alterations in numerous aspects of cellular homeostasis, including proliferation, differentiation, telomere maintenance, and apoptosis (2). BL-derived cell lines are commonly used as model systems to study the biology and evolution of cancer (3). Indeed, Raji, the first continuous human cell line of hematopoietic origin, was established some 40 years ago from a Nigerian patient with BL (4). Shortly thereafter, BL cell lines were found to harbor the EpsteinBarr virus (EBV), leading to the discovery and isolation of this virus (5). The link between EBV and endemic BL proved consistent and became the first of a wide range of associations between this virus and cancer (6).

Recurrent chromosomal abnormalities in hematological malignancies and solid tumors are a powerful resource for the identification of genes with critical roles in cancer (7). Continuous cell lines provide an excellent source of material for the investigation of such genetic changes. However, the karyotypes of most BL-derived cell lines have been studied by conventional G-banding techniques, thus making it difficult to discern the origins of the chromosomes involved in rearrangements. Recent advancements in molecular cytogenetics, including the development of fluorescence in situ hybridization 
(FISH) for gene localization, and protocols for global assessment of genomic imbalances and the simultaneous visualization of structural chromosomal aberrations $(8,9)$, have propelled the analysis of cancer cells to an unprecedented level of resolution. The evolution of cancer cytogenetics is closely linked to the characterization of BL-derived cell lines. Hence, soon after the introduction of differential fluorescence banding (Q-banding) (10), chromosome G-banding and Qbanding studies of biopsies and B cell lines from BL revealed the hallmark translocation $t(8 ; 14)$, one of the first cancerspecific translocations $(11,12)$. Moreover, our group recently performed a comprehensive characterization of the prototypic Raji cell line using the molecular cytogenetic techniques, SKY (spectral karyotyping, involving the simultaneous hybridization of 24 differentially labeled chromosome-painting probes), array-based CGH (comparative genomic hybridization), and FISH, and we demonstrated a number of novel genomic aberrations, concurrent with the $\mathrm{t}(8 ; 14)$ translocation (13). However, for most BL-derived cell lines, a detailed picture of chromosomal abnormalities remains to be determined.

Resistance to apoptosis is one of the cardinal features of cancer cells $(14,15)$. The role of the failure of apoptosis in causing cancer followed the discovery that the $b c l-2$ gene, which is frequently involved in chromosomal translocations in follicular lymphoma, encoded an anti-apoptotic protein (16). When $b c l-2$ was expressed in vitro, it not only protected cells from apoptosis due to growth factor withdrawal, it also prevented apoptosis following treatment with a diverse range of drugs, resulting in a multidrug-resistance phenotype. However, inhibition of apoptosis alone does not rapidly transform cells or cause cancer. In contrast, when inhibition of apoptosis is combined with activation of an oncogene, such as c-myc, cancer can develop very rapidly (17). Moreover, most conventional anti-cancer drugs target the apoptosis machinery of cancer cells, resulting in the activation of a caspase cascade and dismantling of the cell; conversely, alterations in apoptotic pathways in malignant cells contribute to their chemoresistance (18). The characterization of specific defects in apoptosis signaling pathways in cancer cells may thus explain the mechanism of chemoresistance and could also yield novel targets for treatment.

In the present study, we performed a comprehensive analysis of chromosomal aberrations in a panel of $10 \mathrm{BL}-$ derived B cell lines, many of which are widely used in cancer research, based on spectral karyotyping (SKY) and comparative genomic hybridization (CGH). Furthermore, we aimed to assess whether specific patterns of karyotypic abnormalities were associated with the reaction of these cell lines to a common chemotherapeutic drug (etoposide) through in vitro cell-cycle/apoptosis profiling of the cell lines, a process we have termed 'apoptyping'.

\section{Materials and methods}

Cell lines and culture conditions. Burkitt's lymphoma (BL)derived B cell lines, Akata, BL-28, BL-41, Daudi, DG-75, Mutu I, Mutu III, Namalwa, Rael, and Ramos, were obtained from the tissue culture collections of the Microbiology and Tumor Biology Center at Karolinska Institutet. The original references and Epstein-Barr virus (EBV) status of these cell
Table I. BL-derived cell lines used in the present study.

\begin{tabular}{lccl}
\hline Cell line & Gender & EBV status & \multicolumn{1}{c}{ Author/(Refs.) } \\
\hline Akata & F & Pos. & Takada et al $(63)$ \\
BL-28 & M & Neg. & Lenoir et al (64) \\
BL-41 & M & Neg. & Lenoir et al (64) \\
Daudi & M & Pos. & Klein et al (65) \\
DG-75 & M & Neg. & Ben-Bassat et al (66) \\
Mutu I & M & Pos. & Gregory et al (27) \\
Mutu III & M & Pos. & Gregory et al (27) \\
Namalwa & n.a. & Pos. & Nadkarni et al (67) \\
Rael & n.a. & Pos. & Klein et al (68) \\
Ramos & M & Neg. & Klein et al (69) \\
\hline
\end{tabular}

EBV, Epstein-Barr virus; n.a., not available.

lines are shown in Table I. Mutu I and Mutu III are both derived from the same patient, but are phenotypically distinct: Mutu I expresses only EBNA-1 but not the other EBV-encoded EBNAs whereas Mutu III expresses all 6 EBNAs and the 3 latent membrane proteins (LMPs) and has a lymphoblastoid phenotype (19). The human T leukemia cell line, Jurkat, was purchased from the European Collection of Cell Cultures (Salisbury, UK). All cell lines were cultured in RPMI-1640 medium (Gibco, Invitrogen, Carlsbad, CA, USA) supplemented with $10 \%$ fetal calf serum, $2 \mathrm{mM} \mathrm{L-glutamine,} \mathrm{and} 1 \%$ penicillin/streptomycin.

QF-PCR analysis. Genomic DNA was extracted by InstaGene Matrix (Bio-Rad Laboratories, Hercules, CA, USA) according to the manufacturer's protocol with slight modifications. Briefly, $50 \mu 1$ of confluent cells ( 300 cells) were collected

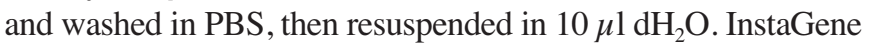
Matrix $(100 \mu \mathrm{l})$ was then added and samples were incubated at $56^{\circ} \mathrm{C}$ for $30 \mathrm{~min}$. Following incubation, samples were vortexed, maintained at $100^{\circ} \mathrm{C}$ for $8 \mathrm{~min}$, and centrifuged at $14,000 \mathrm{rpm}$ for $2 \mathrm{~min}$. Multiplex quantitative fluorescence polymerase chain reaction (QF-PCR) amplification of genomic DNA from each cell line $(5 \mathrm{ng}$ ) was performed using the ChromoQuant kit (Cybergene AB, Stockholm, Sweden) according to the manufacturer's protocol. Samples were analyzed as previously described $(20,21)$ using an ABI PRISM 3100 Avant genetic analyzer (Applied Biosystems, Foster City, CA, USA) operating with GeneMapper 3.5 software (Applied Biosystems).

Cytogenetics. Cells were harvested after mitotic arrest using colcemid (Invitrogen) and metaphase slides were prepared according to standard protocols. Twenty to fifty metaphases were analyzed for each cell line, and the karyotypes were described according to the International Conventional System for Human Cytogenetic Nomenclature (ISCN) (22).

SKY analysis. Spectral karyotyping was performed according to the protocol included in the Human Spectral Karyotyping Kit (Applied Spectral Imaging, Migdal Haemek, Israel). 
Table II. QF-PCR analysis of the BL-derived cell lines.

\begin{tabular}{|c|c|c|c|c|c|c|c|c|c|c|c|c|}
\hline \multirow{2}{*}{$\begin{array}{l}\text { Chromo- } \\
\text { some }\end{array}$} & \multirow[b]{2}{*}{ Marker location } & \multicolumn{11}{|c|}{ Cell line } \\
\hline & & Akata & BL-28 & BL-41 & Daudi & DG-75 & Mutu I & Mutu III & Namalwa & Rael & Ramos & Jurkat \\
\hline \multirow{8}{*}{13} & \multirow{2}{*}{ 13q11-q21.1 } & 260 & 266 & 266 & 258 & 244 & 258 & 258 & 260 & 260 & 270 & 270 \\
\hline & & 282 & 290 & 282 & 276 & 272 & 288 & 288 & 274 & 264 & 274 & 284 \\
\hline & \multirow{2}{*}{$13 q 12.1-q 14.1$} & 450 & 446 & \multirow{2}{*}{441} & 426 & 453 & 450 & 450 & \multirow{2}{*}{450} & 426 & \multirow{2}{*}{446} & \multirow{2}{*}{450} \\
\hline & & 453 & $461 ?$ & & 434 & 457 & 453 & 453 & & 446 & & \\
\hline & \multirow{2}{*}{$13 q 14.3-q 22$} & 400 & 388 & 400 & 390 & 396 & 403 & 403 & \multirow{2}{*}{396} & \multirow{2}{*}{396} & 400 & \multirow{2}{*}{396} \\
\hline & & 406 & 400 & $409 ?$ & 396 & 420 & 424 & 421 & & & 409 & \\
\hline & \multirow{2}{*}{$13 q 31-q 32$} & 428 & 428 & 456 & 446 & 458 & 454 & 454 & 454 & 454 & 428 & 448 \\
\hline & & 430 & 454 & $462 ?$ & 454 & 462 & 458 & 458 & 458 & 458 & 430 & 458 \\
\hline \multirow{7}{*}{18} & \multirow{2}{*}{ 18pter-p11.22 } & 159 & 159 & \multirow{2}{*}{163} & \multirow{2}{*}{163} & 159 & \multirow{2}{*}{154} & \multirow{2}{*}{154} & 150 & 154 & 154 & \multirow{2}{*}{159} \\
\hline & & 163 & 163 & & & 163 & & & 166 & 163 & 166 & \\
\hline & \multirow{2}{*}{$18 \mathrm{q} 12.2-\mathrm{q} 12.3$} & 482 & 478 & 478 & \multirow{2}{*}{486} & \multirow{2}{*}{476} & 476 & 476 & 470 & \multirow{2}{*}{478} & 482 & 466 \\
\hline & & 486 & 482 & 490 & & & 482 & 482 & 482 & & 490 & 480 \\
\hline & \multirow{2}{*}{$18 \mathrm{q} 22.1-\mathrm{q} 22.2$} & 350 & 358 & 358 & 354 & 364 & 358 & 358 & 344 & & 350 & 366 \\
\hline & & 354 & 392 & 380 & 358 & $380 ?$ & 364 & 364 & 344 & 358 & 354 & 376 \\
\hline & $18 q 22.3-q 23$ & 177 & 180 & 180 & 172 & $\begin{array}{l}159 \\
177 ?\end{array}$ & 180 & 180 & 188 & 184 & 180 & 177 \\
\hline & $21 q 21$ & 248 & 260 & 254 & 264 & 242 & 242 & 242 & 235 & 242 & 252 & 257 \\
\hline & & 257 & 275 & & 268 & 254 & 252 & 252 & 239 & 252 & 202 & 264 \\
\hline & 219221 & 453 & 451 & 459 & 451 & 455 & 451 & 451 & 445 & 445 & 453 & 459 \\
\hline 21 & 2142.1 & 461 & 401 & 4 & 455 & 461 & 455 & 455 & $455 ?$ & $4+3$ & 461 & 45 \\
\hline & $21 \mathrm{a} 221$ & 480 & 480 & 473 & 473 & 473 & 480 & 480 & 476 & 476 & 479 & 473 \\
\hline & $21 \mathrm{q} 22.1$ & 486 & 495 & 485 & $4 / 3$ & 476 & 489 & 489 & 492 & 480 & 491 & 489 \\
\hline & 21g22.2-ater & 270 & 273 & 270 & 270 & 286 & 273 & 273 & 270 & 270 & 270 & 295 \\
\hline & & 300 & 276 & 294 & 279 & 295 & 213 & 213 & 270 & 270 & 286 & 293 \\
\hline & $\mathrm{Xq} 26$ & 101 & 105 & 105 & 105 & 109 & 93 & 93 & 101 & 113 & 99 & 113 \\
\hline & Xq26.1 & 290 & $\begin{array}{l}266 \\
282\end{array}$ & 290 & 294 & 290 & 286 & 286 & 294 & 284 & 290 & 290 \\
\hline $\mathrm{X} / \mathrm{Y}$ & Xp22.1-p22.31 & 104 & 104 & 104 & 104 & 104 & 104 & 104 & 104 & 104 & 104 & 104 \\
\hline (AMEL) & $\mathrm{Yq}$ & - & 109 & 109 & 109 & 109 & 109 & 109 & - & - & - & 109 \\
\hline $\mathrm{X} / \mathrm{Y}$ & $\mathrm{Xg} / \mathrm{Yq}$ & 218 & 202 & 200 & 204 & - & 200 & 200 & 200 & 224 & 200 & 204 \\
\hline & $\Lambda q / 1 q$ & 210 & 220 & 214 & 224 & - & 224 & 224 & 200 & 224 & 200 & 207 \\
\hline Y & Yp11.3 & - & $\begin{array}{l}205 \\
207\end{array}$ & 203 & 203 & 203 & 203 & 203 & - & - & - & 201 \\
\hline
\end{tabular}

QF-PCR markers were from the ChromoQuant kit (Cybergene $\mathrm{AB}$ ) and the analysis was performed as detailed in Materials and methods. ? indicates possible trisomy. 
Table III. Composite karyotypes of the BL-derived cell lines, as determined by SKY and CGH.

\begin{tabular}{|c|c|}
\hline Cell line & Karyotype \\
\hline Akata & $\begin{array}{l}\text { 47,X,-X,t(4;11)(p16.3;q13),+i(5)(p10),t(8;14)(q24;q32),der(13)t(2;13)(p12;p11), } \\
\operatorname{der}(14 ; 15)(\mathrm{q} 10 ; \mathrm{q} 10),+\operatorname{der}(20) \mathrm{t}(13 ; 20)(\mathrm{q} 14 ; \mathrm{q} 13.3) \times 2[18] / 47, \operatorname{idem}, \mathrm{t}(3 ; 22)(\mathrm{q} 29 ; \mathrm{q} 11)[3] / \\
47, \operatorname{idem}, \operatorname{der}(15) \mathrm{t}(15 ; 18)(\mathrm{q} 22 ? ; \mathrm{q} 23 ?)[4]\end{array}$ \\
\hline BL-28 & $47, \mathrm{XY}, \mathrm{t}(8 ; 14)(\mathrm{q} 24 ; \mathrm{q} 32), \operatorname{dup}(12)(\mathrm{q} 22 \mathrm{q} 24.1), \operatorname{del}(13)(\mathrm{q} 21 \mathrm{q} 22),+13, \operatorname{dup}(16)(\mathrm{p} 11.2 \mathrm{p} 13.1)[18]$ \\
\hline BL-41 & $\begin{array}{l}45, \mathrm{XY}, \operatorname{der}(2) \mathrm{t}(2 ; 16)(\mathrm{q} 35 ; \mathrm{q} 12), \operatorname{del}(3)(\mathrm{q} 13.2 \mathrm{q} 13.3), \operatorname{der}(4) \mathrm{t}(4 ; 18)(\mathrm{q} 13 ; \mathrm{q} ?),+\operatorname{der}(7) \mathrm{t}(4 ; 7)(\mathrm{q} 21 ; \mathrm{p} 21), \\
\operatorname{der}(8) \mathrm{t}(8 ; 10)(\mathrm{p} 23 ; \mathrm{q} 11.2), \mathrm{t}(8 ; 14)(\mathrm{q} 24 ; \mathrm{q} 32),-10, \operatorname{dup}(13)(\mathrm{q} 14 \mathrm{q} 31), \operatorname{der}(15) \mathrm{t}(3 ; 15)(\mathrm{q} 21 ; \mathrm{p} 11.1), \\
\operatorname{der}(17) \mathrm{t}(3 ; 17)(\mathrm{q} 21 ; \mathrm{p} 11.2),-18[19]\end{array}$ \\
\hline Daudi & $47, \mathrm{XY},+7, \mathrm{t}(8 ; 14)(\mathrm{q} 24 ; \mathrm{q} 32)[26] / 47, \mathrm{idem}, \operatorname{der}(2) \mathrm{t}(2 ; 15)(\mathrm{q} 34 ? ; \mathrm{q} 22 ?)[2]$ \\
\hline DG-75 & 46,XY,der(4)t(4;18)(q31.3;q12),t(8;14)(q24;q32)[19]/92,idemx2[6] \\
\hline Mutu I & $46, X Y, t(8 ; 14)(q 24 ; \mathrm{q} 32),+20$ \\
\hline Mutu III & $\begin{array}{l}58 \sim 79, \mathrm{XXY},+\mathrm{Y},-1,+2,-2,+\mathrm{i}(2)(\mathrm{p} 10),+\mathrm{i}(3)(\mathrm{q} 10),-4, \operatorname{der}(4) \mathrm{t}(4 ; 14)(\mathrm{q} ? ; \mathrm{q} ?), \operatorname{der}(4)(4 ; 14 ; 20)(\mathrm{q} ? ; \mathrm{q} ? ; \mathrm{q} ?), \\
-5,+6,-6, \operatorname{der}(6 ; 13)(\mathrm{q} ? ; \mathrm{q} ?),+7, \operatorname{dup}(8)(\mathrm{p} 21 \mathrm{q} 23),-8, \mathrm{t}(8 ; 14) \mathrm{t}(\mathrm{q} 24 ; \mathrm{q} 32) \times 2,-9,+10,-10,+11,-11,-12,+\operatorname{del}(12)(\mathrm{q} ?), \\
-13,-14,+16,+\operatorname{der}(16) \mathrm{t}(15 ; 16)(\mathrm{q} 1 ? ; \mathrm{q} 24),-17,-18,+19,-19,+20,+21,-21,+22,-22[\mathrm{cp} 27]\end{array}$ \\
\hline Namalwa & $\begin{array}{l}\text { 47,X,-Y?,dup(1)(q12q25),t(2;8)(p11;q24.3),del(3)(p11.1p21),der(3)t(3;5)(q29;q22?),del(5)(q22?),+7, } \\
\mathrm{t}(8 ; 14)(\mathrm{q} 24 ; \mathrm{q} 32), \operatorname{der}(10) \mathrm{t}(3 ; 10)(\mathrm{q} 26.2 ; \mathrm{p} 15.3), \operatorname{der}(12) \mathrm{t}(3 ; 12)(\mathrm{q} 24 ; \mathrm{p} 13.3), \operatorname{del}(14)(\mathrm{q} 13 \mathrm{q} 22), \\
+\operatorname{der}(14) \mathrm{t}(8 ; 14)(\mathrm{q} 24 ; \mathrm{q} 32), \operatorname{der}(15) \mathrm{t}(15 ; 15)(\mathrm{p} 11 ; \mathrm{q} 24), \operatorname{ins}(17 ; 1)(\mathrm{p} 11 ; \mathrm{p} 22 \mathrm{p} 31)[6] / \\
47, \operatorname{idem},-\operatorname{der}(10) \mathrm{t}(3 ; 10)(\mathrm{q} 26.2 ; \mathrm{p} 15.3),+10,-\operatorname{der}(15) \mathrm{t}(15 ; 15)(\mathrm{p} 11 ; \mathrm{q} 24), \operatorname{der}(15) \mathrm{t}(1 ; 15)(\mathrm{p} ? ; \mathrm{p} 11)[4] / \\
47, \operatorname{idem},-\mathrm{t}(2 ; 8)(\mathrm{q} 11 ; \mathrm{q} 24.3), \operatorname{der}(2) \mathrm{t}(1 ; 2)(\mathrm{p} ? \mathrm{p} 11), \operatorname{der}(8) \mathrm{t}(2 ; 8) \mathrm{t}(\mathrm{p} 11 ; \mathrm{q} 24.3)[2]\end{array}$ \\
\hline Rael & 44,X,-Y?,del(9)(q21q22),der(9;17)(p10;p10),t(8;14)(q24;q32),der(9;15)(q10;q10),-17,i(17)(q10)[12]/45,idem,+20[9] \\
\hline Ramos & $\begin{array}{l}45, X,-Y, \operatorname{del}(3)(\mathrm{p} 14 \mathrm{p} 14), \mathrm{t}(8 ; 14)(\mathrm{q} 24 ; \mathrm{q} 32) \\
\text { psu } \operatorname{dic}(7 ; 16)(\mathrm{p} 11 ; \mathrm{p} 13), \operatorname{der}(17) \mathrm{t}(3 ; 13 ; 17)(\mathrm{q} 25 ; \mathrm{q} 31 \mathrm{q} 14 ; \mathrm{p} 11.1)[15] / \\
48, \operatorname{idem},+\operatorname{der}(7) \mathrm{t}(2 ; 7)(\mathrm{p} 16 ; \mathrm{q} 32), \operatorname{der}(13) \mathrm{t}(3 ; 13)(\mathrm{q} 25 ; \mathrm{q} 31),+17,+20[24]\end{array}$ \\
\hline
\end{tabular}

Briefly, cocktail probe was hybridized on 1-day old pepsintreated metaphase slides. Slides were then incubated with Cy5 and Cy5.5 detection reagents (Applied Spectral Imaging) and counterstained with 4,6-diamino-2-phenylindole (DAPI) dissolved in an anti-fade solution (Vectashield, Vector Inc., Burlingame, CA, USA). Images were acquired using SD200 Spectral Imaging System version 1.41, consisting of a Spectral cube and CCD camera (Applied Spectral Imaging) mounted on a Zeiss Axioscope2 microscope (Zeiss, Jena, Germany). Image analysis was performed using SkyView 2.1 and Case Data Manager EXPO 2.0 software (Applied Spectral Imaging).

CGH analysis. CGH was performed essentially as described previously (23). Genomic DNA from cell lines and reference DNA (Promega, Mannheim, Germany) was digested into fragments of 100-2,000 bp using DpnII (New England Biolabs, Beverly, MA, USA). The resulting DNA fragments were purified and the DNA was directly labeled by Universal Linkage System ULS (Q-BIOgene Molecular Cytogenetics, Illkirch, France) according to the manufacturer's instructions. Reference DNA was labeled with rhodamine (Q-BIOgene) and sample DNA was labeled with dGreen (Q-BIOgene). Samples were then mixed and re-purified using the PCR purification kit (Qiagen, Hilden, Germany), Cot-1 DNA
(Invitrogen) was added prior to ethanol precipitation, and the pellet was resuspended in Hybrisol VI solution (Q-BIOgene). Labeled DNA was then applied onto metaphase slides from normal lymphocyte cultures. After overnight hybridization, the slides were washed and counterstained with DAPI. Nonoverlapping chromosomes were analyzed on a Zeiss Axioplan2 fluorescence microscope and images were captured with a cooled CCD camera (SenSys Photometrics, München, Germany) operating with SmartCapture software (Digital Scientific, Cambridge, UK). Data analysis was performed using the Quips software from Vysis (Downers Grove, IL, USA).

Apoptosis/cell-cycle analysis. For induction of apoptosis, BL-derived cell lines or Jurkat $\mathrm{T}$ cells in logarithmic growth phase were incubated for $24 \mathrm{~h}$ in the presence or absence of etoposide $(6 \mu \mathrm{g} / \mathrm{ml})$ (Bristol-Myers Squibb, Stockholm, Sweden). Simultaneous assessment of apoptosis and cellcycle distribution was then performed according to standard procedures (24). Briefly, cells were harvested, fixed in ethanol for $12 \mathrm{~h}$, and stained with propidium iodide/RNase readymade solution (Becton-Dickinson, San Jose, CA, USA). Cells were then analysed on a FACScan (Becton-Dickinson) equipped with a 488-nm argon laser using CellQuest software (Becton-Dickinson). Data were depicted as histograms and 
the percentages of cells displaying hypodiploid DNA content (sub-G1 phase) versus cells contained in the G1 and G2-M phase of the cell cycle were determined.

\section{Results}

Cross-contamination analysis by QF-PCR of 10 human BLderived $B$ cell lines. Quantitative fluorescence polymerase chain reaction (QF-PCR) is a standard method in prenatal diagnostics and is employed for the rapid identification of aneuploid disorders and aberrations involving sex chromosomes (25). We decided to use QF-PCR for the analysis of genomic DNA from our panel of BL-derived cell lines, in order to establish the unique origin of each cell line prior to embarking on laborious karyotyping studies. The Jurkat cell line, a classic leukemia cell line that accounts for numerous cases of cross-contaminations among other leukemialymphoma cell lines (26), was included for comparison. With this rapid method, sex determination of each of the $10 \mathrm{BL}$ cell lines was easily performed, and the results were found to be in concordance with the original references (Table I). Furthermore, QF-PCR confirmed the relationship between the Mutu I and Mutu III cell lines (27), whereas all other cell lines were shown not to be related (Table II). Hence, crosscontamination of the BL-derived cell lines was excluded.

Identification of hidden chromosomal aberrations by spectral karyotyping $(S K Y)$ of BL-derived cell lines. Numerical and structural chromosomal aberrations were identified by SKY in each of the BL-derived cell lines; the majority of these aberrations have not been reported previously. A full description of the karyotypes is presented in Table III. Hence, we identified a total of 41 numerical and 63 structural aberrations (45 translocations, 8 deletions, 9 duplications, and 1 insertion). All cell lines harbored the hallmark translocation, $\mathrm{t}(8 ; 14)(\mathrm{q} 24 ; \mathrm{q} 32)$, and at least one additional aberration (range: 2-11 aberrations per cell line); the highest number of chromosomal aberrations was observed in the Namalwa cell line. None of the non$\mathrm{t}(8 ; 14)$ aberrations were common to all BL cell lines. However, several frequently recurring abnormalities were observed, including trisomy 7 , trisomy 20 , and translocations involving chromosomes 3, 13, and 17. Even for cell lines that appeared to be similar upon QF-PCR analysis, the spectral karyotypes were found to be markedly different. The special case of the Mutu cell lines (derived from the same patient) is of particular interest, and indicates that variations in the program of EBV latency may have a dramatic impact on the genetic constitution of a cell line (Table III). Furthermore, the complexity of some of the observed translocations [such as $\operatorname{der}(3 ; 13 ; 17)$ in the Ramos cell line, or $\operatorname{der}(4 ; 14 ; 20)$ in the Mutu III cell line] suggests how they could have been overlooked by conventional G-banding techniques. SKY analysis, on the other hand, unequivocally characterized all abnormal chromosomes, leaving no markers of unknown origin. SKY derivative chromosomes, i.e. those chromosomes displaying translocations, insertions, or numerical aberrations, are shown for each cell line in Fig. 1. Since chromosomal breakpoints of all translocations cannot always be determined by this method, additional CGH analysis, and a comparison of inverted DAPI banding with the CGH profiles, was performed.
Table IV. Chromosomal imbalances and breakpoints detected by $\mathrm{CGH}$.

\begin{tabular}{lc}
\hline Cell line & Losses \\
\hline Akata & - \\
& \\
BL-28 & - \\
& \\
BL-41 & 2q35-qter, 3q13.2-q13.3, 4q13, \\
& 10pter-q11.2, \\
& 17pter-p12
\end{tabular}

Daudi

DG-75

4q32-qter

Gains

Mutu I 2p12-pter, 5pter-q11.2, 13q14-qter, 20

12q22-24.1, 13q12-q14, 13q31-qter, 16p11.2-p13.1

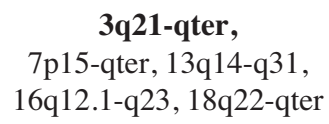

7

Mutu III

18q12-qter

20

Namalwa 3p11.1-p21, 14q14-q22, 17p

2p, 3q, 8p22-pter, 16p13.1-q21

1q12-q25, 1p31-p32, 1p35-pter, 3q24-qter,

7, 8q23-qter, 14q11-q13,

14q31-qter, 15q24-qter

Rael

9q21-q22, 17p11.2-pter

Ramos

3p14, 13q32-qter

2p16-p24, 3q25-qter, 7 (7q10-q32), 13q14-q31, 17p11.1-17qter, 20

Designations in bold denote areas of amplifications (defined as fluorescence intensity values $\geq 2.0$; see Fig. 2 for representative ratio profiles).

Assignment of chromosomal breakpoints and imbalances in $B L$ cell lines by CGH analysis. To determine the breakpoints of chromosomal rearrangements, and to detect genomic losses and gains, the $10 \mathrm{BL}$ cell lines were subjected to metaphase $\mathrm{CGH}$ analysis. We identified a total of 49 breakpoints in rearranged chromosomes. Partial CGH profiles for the Akata, BL-41, and Mutu III cell lines, illustrating the criteria for gains and losses, are depicted in Fig. 2. In general, there were no whole chromosome losses in our panel of cell lines, and more gains than losses of genomic material were observed. Recurring breaks (two or more) were noted at 13q14, 13q31, and 16p13.1 (Fig. 3). Whole chromosome gains were found to affect chromosomes 7 and 20, whereas regional gains often occurred on $3 q$ and $13 q$, less often on $2 p$ and $16 q$, and in a few cases on 1q, 1p, 5p, 8q, 12q, 14q, 15q, 17q, and 18q. Regional losses most often occurred on $3 p, 4 q$, and $17 p$, and were also noted on 2q, 3q, 9q, 10p, 13q, 14q, and 18q. Regions of high-level gain (amplifications) were detected at six sites: 3q21-qter (BL-41), 3q25-qter (Ramos), 5pter-q11.2 (Akata), 7q10-q32 (Ramos), 13q14-qter (Akata), and chromosome 20 (Akata). Combined CGH results from all 10 cell lines revealed several common regions of gains and losses of genomic material, such as 2p16-pter, 3q25-qter, 7q11.2-q32, 16q12.1$\mathrm{q} 21,13 \mathrm{q} 14$, and 13q31 (gains), and 3p14 and 17p (losses). All abnormalities detected by CGH are listed in Table IV, 


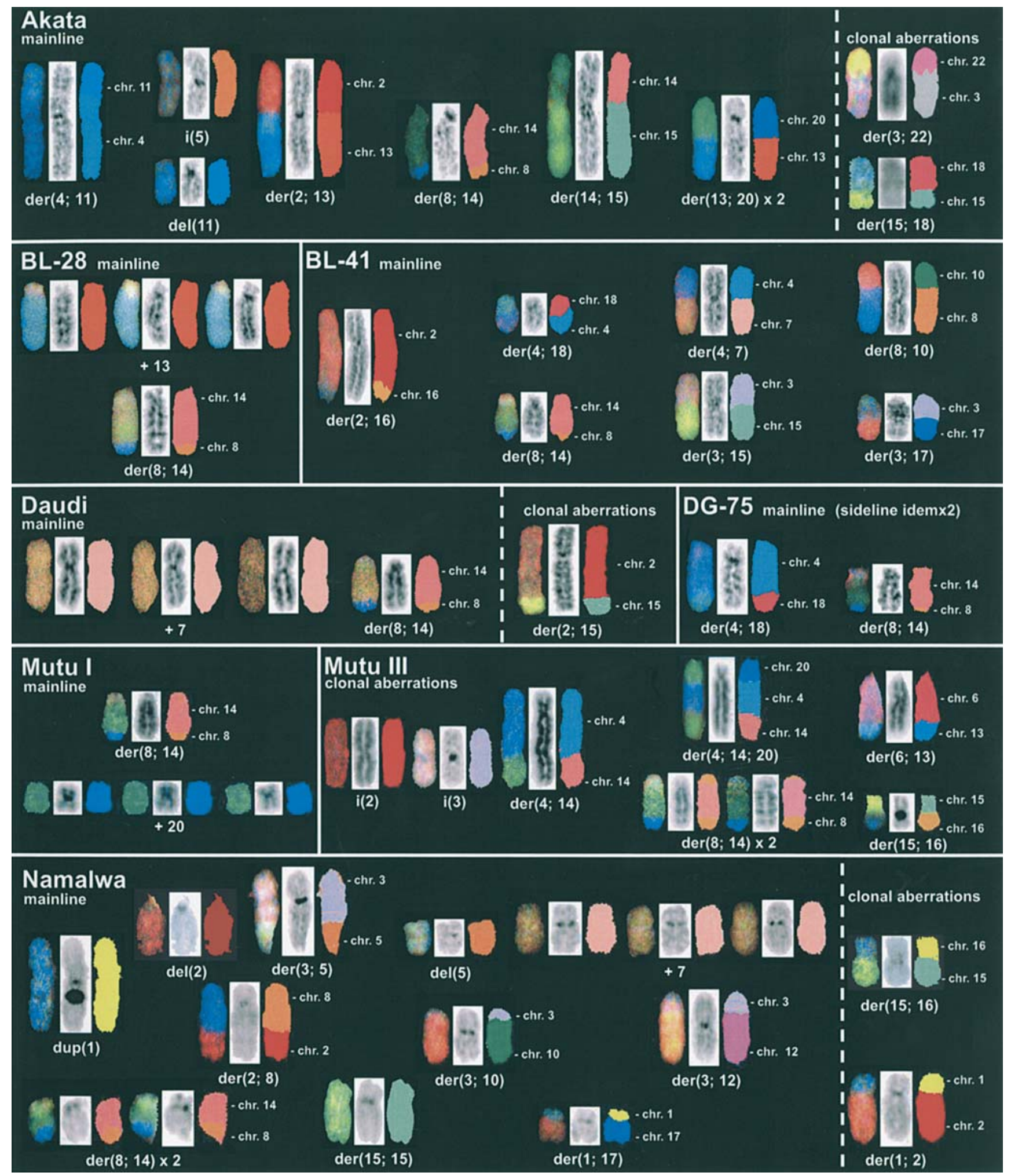

Figure 1. Spectral karyotyping of 10 BL-derived BL cell lines. Shown from left to right for each derivative chromosome are hybridization display colours, grayscale inverted 4,6-diamino-2-phenylindole (DAPI) images, and SKY classification colours. Clonal aberrations are also depicted. Note the presence of the characteristic $\mathrm{t}(8 ; 14)$ translocation in all 10 cell lines.

and the combined $\mathrm{CGH}$ profiles of all $10 \mathrm{BL}$ cell lines are presented in Fig. 3. Some breakpoints in rearranged chromosomes were not identified (for instance, aberrations present in sublines may not be detected by standard metaphase $\mathrm{CGH}$ ). Nonetheless, there was, overall, a remarkable correspondence between imbalances in the CGH profiles and the numerical alterations detected by SKY analysis, and these studies thus underscore the usefulness of a combined analysis in detecting genomic changes in cancer cells.

Comparison between molecular karyotypes of BL cell lines and $G$-banding of cell lines and primary BL tumors. We performed a detailed comparison of the karyotypes of BL cell lines obtained with molecular cytogenetic techniques and 

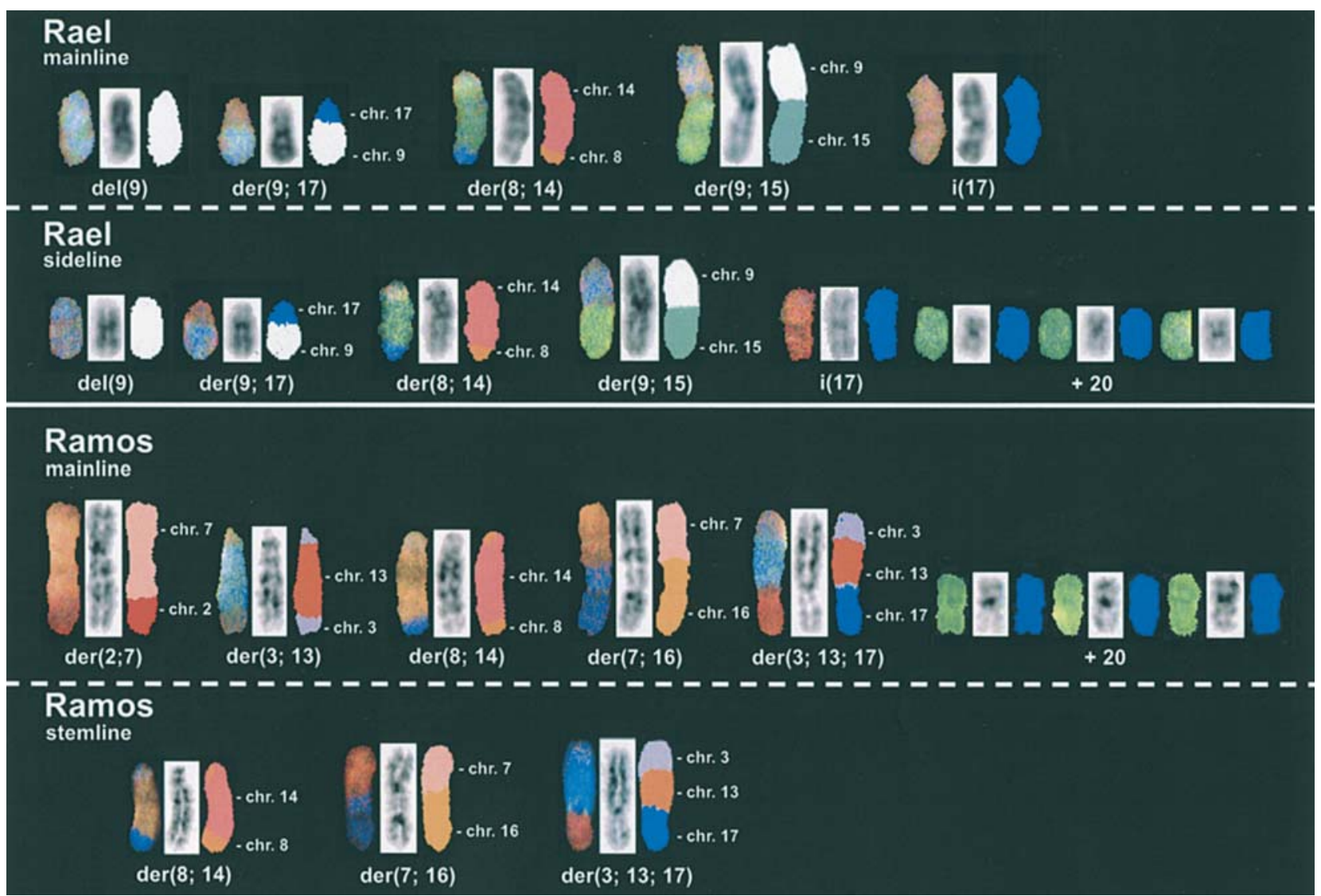

Figure 1. Continued.

Akata

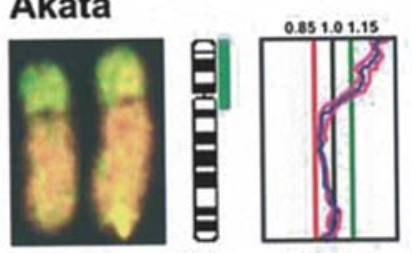

Chromosome 5

BL-41

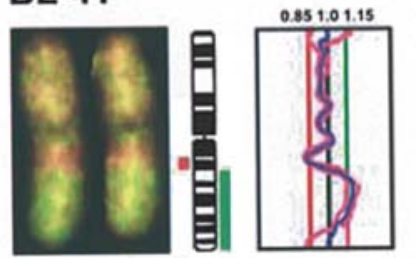

Chromosome 3

Mutu III
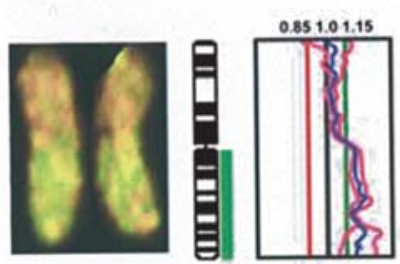

Chromosome 3
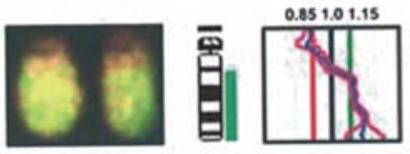

Chromosome 13
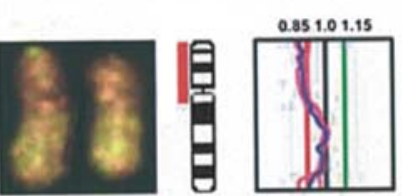

Chromosome 10

Namalwa
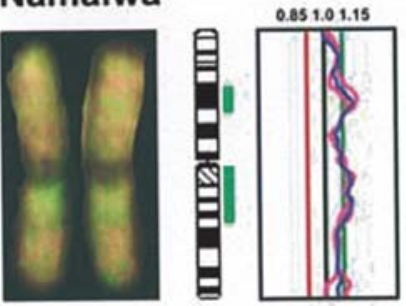

Chromosome 1

Figure 2. Partial CGH profiles of 3 representative BL cell lines illustrating the criteria for gains and losses of genomic material. The blue line in the ratio profile (right) represents the mean of the two chromosomes depicted to the left. Sample-to-reference ratios of $\geq 0.8$ and $\leq 1.2$ were considered normal; the vertical green and red bars on the right and left of the ideogram designate gains and losses, respectively. 
A

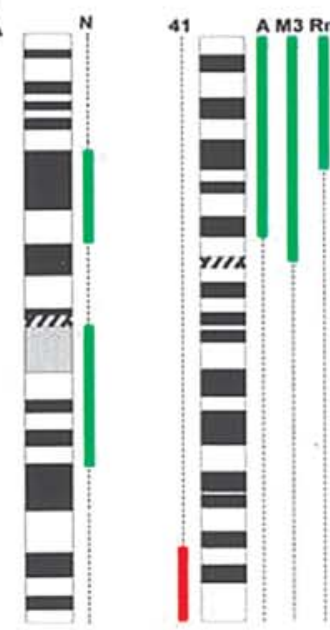

Chr. 1

Chr. 2

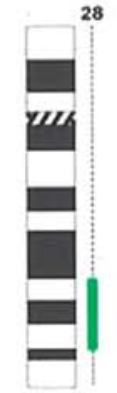

Chr. 12

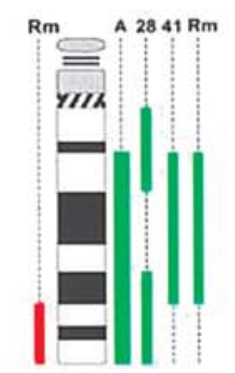

Chr. 13

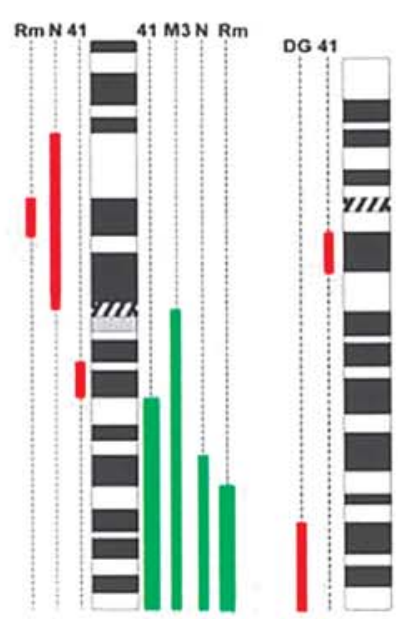

Chr. 3

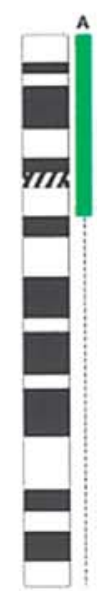

Chr. 5
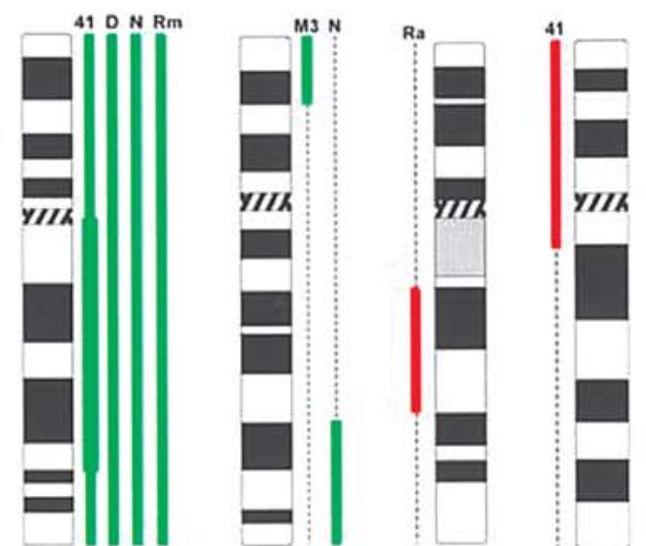

Chr. 7

Chr. 8

Chr. 9 Chr. 10

B

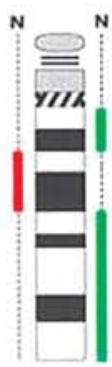

Chr. 14

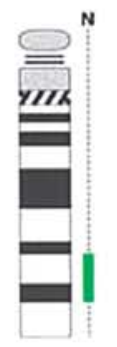

Chr. 15

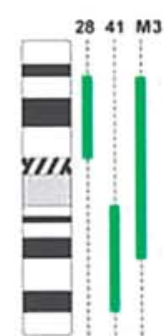

Chr. 16

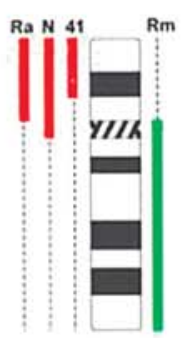

Chr. 17

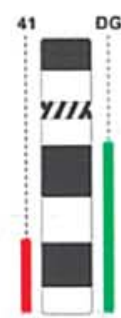

Chr. 18

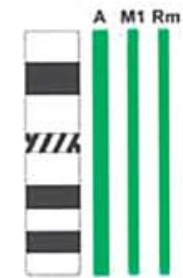

Chr. 20

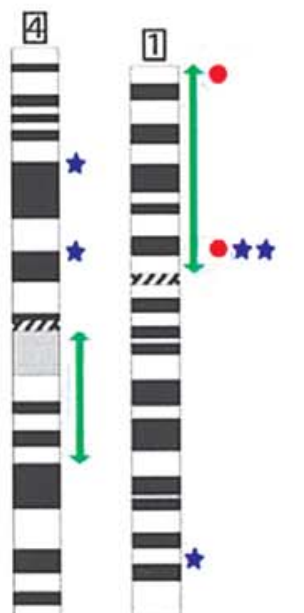

Chr. 1 Chr. 2

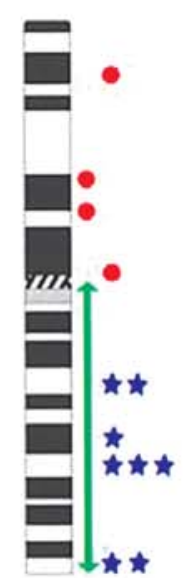

Chr. 3

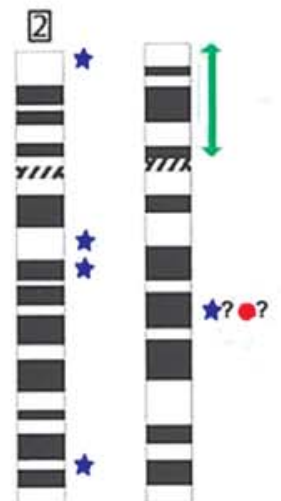

Chr. 4 Chr. 5

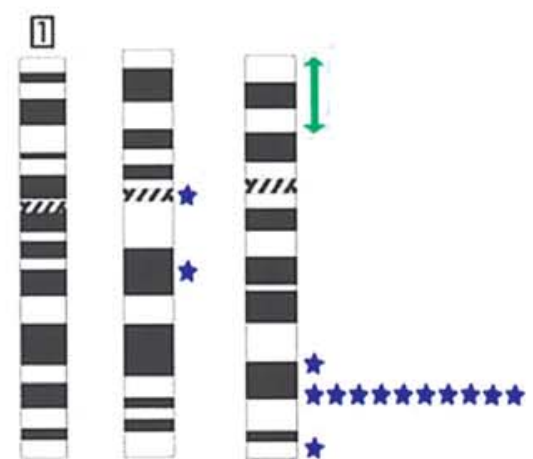

$\begin{array}{lll}\text { Chr. } 6 & \text { Chr. } 7 & \text { Chr. } 8\end{array}$

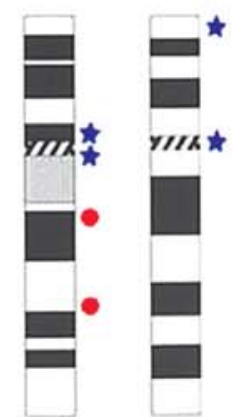

Chr. 9 Chr. 10

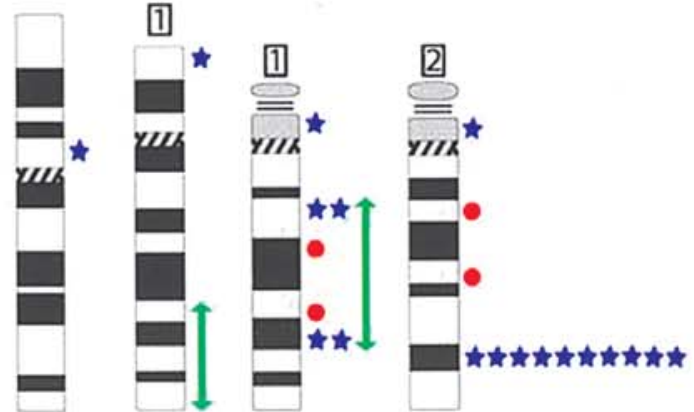

Chr. 11 Chr. 12 Chr. 13

Chr. 14

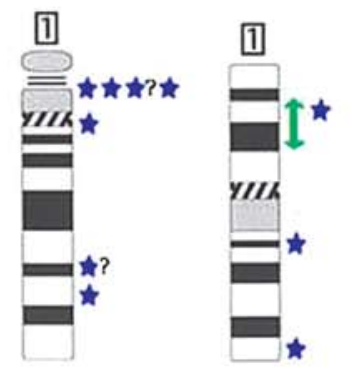

Chr. 15

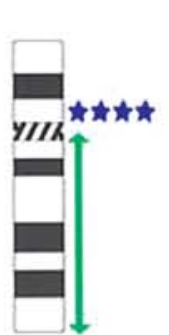

Chr. 17

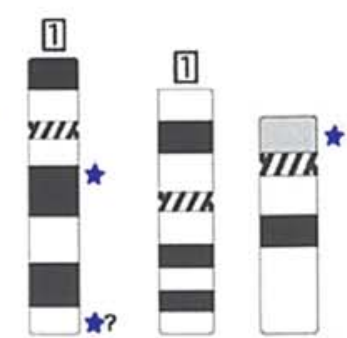

Chr. 18 Chr. 20 Chr. 22

Figure 3. Ideograms showing DNA copy number changes identified by CGH in the $10 \mathrm{BL}$ cell lines. (A) The vertical lines on either side of the ideogram indicate losses (left) and gains (right) of the chromosomal region. Thick green lines indicate regions with high-level gains (amplifications). (B) Ideograms showing all of the chromosomal breakpoints noted in the BL cell lines using SKY (inverted DAPI images) in combination with CGH. Blue stars indicate breakpoints of translocations, and stars with a question mark indicate a breakpoint for which the localization remains uncertain. Red circles indicate breakpoints for deletions, green arrows depict duplications. Numbers above chromosomes indicate how many unidentified breakpoints are assigned to the chromosome. 
Table V. G-banded karyotypes and p53 status of the BL cell lines.

\begin{tabular}{|c|c|c|c|}
\hline Cell line & TP53 status & Previous karyotypes & Author/(Refs.) \\
\hline Akata & Mutant ${ }^{\mathrm{a}}$ & $46, X 0, t(8 q-, 14 q+),+20$ & Takada et al (63) \\
\hline BL-28 & $\mathrm{WT}^{\mathrm{b}}$ & $46, X X, t(8 ; 14), \operatorname{dup}(1)(q 23-q 25), 19 q+$ & Berger and Bernheim (72) \\
\hline BL-41 & Mutant ${ }^{\mathrm{c}}$ & $\begin{array}{l}48(42-49, \mathrm{XY},+7,-13,+2 \operatorname{mar}, \operatorname{add}(8)(\mathrm{q} 24), \mathrm{t}(8 ; 14)(\mathrm{q} 24 ; \mathrm{q} 32) \\
\operatorname{der}(15) \mathrm{t}(13 ; 15)(\mathrm{q} 13 ; \mathrm{p} 11), \operatorname{add}(17)(\mathrm{p} 12)\end{array}$ & Drexler et al (73) \\
\hline Daudi & $\begin{array}{c}\text { Mutant }^{\mathrm{d}} \\
\text { (nonsense) }\end{array}$ & $\begin{array}{l}48 X Y,-5,+7, \mathrm{t}(8 ; 14),+11 \mathrm{p}-\mathrm{q}-,-15 \mathrm{q}-,+ \text { marker } \\
46-48, \mathrm{XY}, \mathrm{t}(8 ; 14),+6,+7, \mathrm{del}(15)(\mathrm{q} 13-\mathrm{q} 15) \\
46(45-48) \mathrm{XY} / \mathrm{XXY},+7,-9, \mathrm{t}(8 ; 14)(\mathrm{q} 24 ; \mathrm{q} 32)\end{array}$ & $\begin{array}{l}\text { Steel } \text { et al (74) } \\
\text { Berger and Bernheim (72) } \\
\text { Drexler } \text { et al (73) }\end{array}$ \\
\hline DG75 & $\mathrm{WT}^{\mathrm{b}}$ & $\begin{array}{l}46, X Y, 14 \mathrm{q}+ \\
46 X Y, t(8 ; 14)(\mathrm{q} 24 ; \mathrm{q} 32)\end{array}$ & $\begin{array}{l}\text { Berger and Bernheim (72) } \\
\text { Drexler } \text { et al (73) }\end{array}$ \\
\hline Mutu I & Mutant ${ }^{b}$ & 'Carried the characteristic translocation' $\mathrm{t}(8 ; 14)$ & Gregory et al (27) \\
\hline \multirow[t]{2}{*}{ Mutu III } & Mutant $^{\mathrm{b}}$ & 'Carried the characteristic translocation' $t(8 ; 14)$ & Gregory et al (27) \\
\hline & & $\begin{array}{l}\text { 'Grossly abnormal’ XX 1p+q+(dupl 1q),3q+,6q-, }+7, t(8 ; 14), \text { inv10,13q+,-15,16q+,-21,-22, } \\
\text { + up to } 6 \text { markers }\end{array}$ & Steel et al (74) \\
\hline Namalwa & $\begin{array}{c}\text { Mutant }^{\mathrm{d}} \\
\text { (missense) }\end{array}$ & $\begin{array}{l}48, \mathrm{X},+7,+18,1 \mathrm{q}+, 3 \mathrm{q}+, \operatorname{del}(3)(\mathrm{p} 11), \operatorname{del}(4)(\mathrm{q} 21), \operatorname{inv}(10), \operatorname{del}(15)(\mathrm{q} 21-\mathrm{q} 24), 46, \mathrm{X}, \mathrm{t}(8 ; 14),+7,+18,-1, \\
\operatorname{dup}(1)(\mathrm{q} 22-\mathrm{q} 25), \operatorname{dup}(3)(\mathrm{q} 13-\mathrm{q} 24), \operatorname{variations} 44(43-46), \mathrm{X},-\mathrm{Y},-5,-6,+7,-10,-13,- \\
21,+3 \mathrm{mar}, \operatorname{ins}(1 ; ?)(\mathrm{p} 11 ; ?), \operatorname{ins}(3)(\mathrm{q} 11 \mathrm{q} 29), \operatorname{der}(5) \mathrm{t}(1 ; 5)(\mathrm{q} 25 ; \mathrm{q} 35), \operatorname{del}(8)(\mathrm{p} 22), \operatorname{der}(14) \mathrm{t}(14 ; ?)(\mathrm{p} 11 ; ?), \\
\operatorname{der}(15) \mathrm{t}(15 ; 21)(\mathrm{p} 11 ; \mathrm{q} 11),+ \text { 'Namalwa' markers }\end{array}$ & $\begin{array}{l}\text { Berger and Bernheim (72) } \\
\text { Drexler et al (73) }\end{array}$ \\
\hline Rael & Mutant ${ }^{\mathrm{b}}$ & n.a. & \\
\hline Ramos & $\begin{array}{c}\text { Mutant }^{\mathrm{d}} \\
\text { (missense) }\end{array}$ & $49 \mathrm{XY}, \mathrm{t}(6,17), \mathrm{t}(7 ; 16), \mathrm{t}(8 ; 14),+7,+2$ markers & Steel et al (74) \\
\hline
\end{tabular}

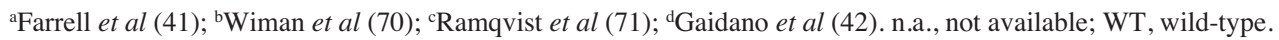

the previously published karyotypes based on conventional cytogenetics of the same cells. Karyotype analysis based on chromosome banding often results in marker chromosomes that are comprised of rearranged fragments whose origin remains ambiguous. By contrast, the origins of all complex rearrangements previously unidentified in G-banding studies were resolved using SKY and CGH (Table V). In addition, several new or hidden aberrations were revealed. However, a correspondence in chromosome numbers and characteristic markers was seen, which allowed us to conclude that the same cell lines have been used. A matter of considerable importance is the relationship between cell lines and the primary tumors from which these cell lines arose. Previous studies show that HeLa (the first human cell line of epithelial origin) (28) and Raji (the first human cell line of hematopoietic origin) $(4,29)$ have remained stable despite many decades of in vitro cultivation $(13,30)$. We conducted a search of the public Mitelman Database to investigate which genetic changes are common for patients with BL, and this list of structural aberrations is presented in Table VI. Several aberrations in our panel of BL cell lines, in addition to $\mathrm{t}(8 ; 14)(\mathrm{q} 24 ; \mathrm{q} 32)$, were either identical to aberrations listed in the patient database or occurred on the same chromosome arm affected in BL patients. Hence, the concordance of our findings suggests that the cell lines characterized herein are relevant models of BL tumors, at least from a cytogenetic perspective.
Apoptyping reveals differences in chromosomal abnormalities between chemosensitive and chemoresistant BL cell lines. Next, we measured DNA content in our panel of BL cell lines incubated in the presence or absence of the chemotherapeutic agent, etoposide. Jurkat cells were included as a positive control. Analysis of flow cytometric profiles focused on three distinct populations of cells: a) a sub-G1 or hypodiploid population, corresponding to cells undergoing apoptosis; b) a G1 population, corresponding to cells in the G1 phase of the cell cycle; and c) a G2-M population, corresponding to dividing cells in the G2 and M phases of the cell cycle (24). Based on this analysis, 3 of the BL cell lines were classified as sensitive (Akata, BL-28, Namalwa) and 5 as resistant (BL-41, Daudi, DG-75, Mutu I, and Mutu III); 2 cell lines (Rael and Ramos) were determined to be intermediate-to-resistant, in comparison to the Jurkat cell line (Fig. 4). The maximal response to etoposide (35\% of sub-G1 cells) was observed in the Namalwa cell line. Furthermore, cell lines classified as sensitive or intermediate displayed either: a) apoptosis + G2-M accumulation (Akata, BL-28, Rael, Ramos), or b) apoptosis + G1 restriction of progression (Namalwa), whereas resistant cell lines showed c) G2-M accumulation (BL-41, DG-75, Mutu I, Mutu III), or d) G1 restriction of progression (Daudi). We also asked whether any specific associations between chromosomal aberrations and apoptosis/cell-cycle profiles of the BL cell lines were evident. Interestingly, a recurrence of specific 
Table VI. Structural aberrations detected in primary BL tumors.

\begin{tabular}{|c|c|c|}
\hline $\begin{array}{l}\text { Chromosome } \\
\text { arm }\end{array}$ & Aberrations & $\begin{array}{l}\text { No. of } \\
\text { cases }\end{array}$ \\
\hline & Balanced translocations & \\
\hline $2 \mathrm{p}$ & $\begin{array}{c}\mathbf{t}(\mathbf{2} ; \mathbf{8})(\mathbf{p} 11 ; \mathbf{q} 24) ; \mathrm{t}(2 ; 8)(\mathrm{p} 12 ; \mathrm{q} 23) \\
\mathrm{t}(2 ; 8)(\mathrm{p} 12 ; \mathrm{q} 24)\end{array}$ & 18 \\
\hline $8 \mathrm{q}$ & $t(8 ; 14)(q 24 ; q 32)$ & 189 \\
\hline $18 \mathrm{q}$ & $\mathrm{t}(14 ; 18)(\mathrm{q} 32 ; \mathrm{q} 21)$ & 6 \\
\hline \multirow[t]{2}{*}{$22 q$} & $\mathrm{t}(8 ; 22)(\mathrm{q} 23 ; \mathrm{q} 12) ; \mathrm{t}(8 ; 22)(\mathrm{q} 24 ; \mathrm{q} 11)$ & 32 \\
\hline & Unbalanced aberrations & \\
\hline $1 p$ & $\operatorname{add}(1)(\mathrm{p} 36)$ & 2 \\
\hline $1 q$ & $\begin{array}{c}\mathrm{i}(1)(\mathrm{q} 10) ; \operatorname{dup}(1)(\mathrm{q} 12 \mathrm{q} 32) \\
\operatorname{dup}(1)(\mathrm{q} 21 \mathrm{q} 31) ; \operatorname{dup}(1)(\mathrm{q} 21 \mathrm{q} 32) \\
\operatorname{dup}(1)(\mathrm{q} 21 \mathrm{q} 44) ; \operatorname{dup}(1)(\mathrm{q} 23 \mathrm{q} 32) \\
\operatorname{del}(1)(\mathrm{q} 25)\end{array}$ & 24 \\
\hline $2 q$ & $\operatorname{del}(2)(\mathrm{q} 32)$ & 3 \\
\hline $3 \mathbf{p}$ & $\operatorname{del}(3)(\mathrm{p} 24)$ & 2 \\
\hline $3 q$ & $\operatorname{del}(3)(\mathrm{q} 21)$ & 2 \\
\hline $6 q$ & $\operatorname{del}(6)(\mathrm{q} 21)$ & 3 \\
\hline $7 \mathbf{q}$ & $\operatorname{add}(7)(q 22)$ & 2 \\
\hline $8 \mathbf{p}$ & $\operatorname{der}(8) \mathrm{t}(1 ; 8)(\mathrm{q} 21 ; \mathrm{p} 11)$ & 2 \\
\hline $9 q$ & $\operatorname{del}(9)(q 22)$ & 2 \\
\hline $13 q$ & $\operatorname{add}(13)(q 34)$ & 7 \\
\hline $14 \mathrm{q}$ & $\operatorname{add}(14)(q 32)$ & 15 \\
\hline $15 p$ & $\operatorname{add}(15)(\mathrm{p} 11)$ & 2 \\
\hline $17 \mathrm{q}$ & $\mathbf{i}(\mathbf{1 7})(\mathbf{q 1 0})$ & 2 \\
\hline $18 \mathrm{q}$ & $\operatorname{add}(18)(\mathrm{q} 21)$ & 2 \\
\hline $22 q$ & $\operatorname{der}(13 ; 22)(q 10 ; q 10)$ & 2 \\
\hline
\end{tabular}

Data were obtained from the Mitelman Database at http://cgap.nci.nih.gov/ Chromosomes/Mitel_Search. Designations in bold indicate aberrations that also occurred in the BL cell lines investigated herein (these aberrations were either identical to those listed in the database, or occurred on the chromosome arm also affected in patient specimens).

abnormalities [apart from the $\mathrm{t}(8 ; 14)$ translocation] was observed. Hence, among the $7 \mathrm{BL}$ cell lines classified as resistant or intermediate, translocations involving $17 \mathrm{p}$, gain of most of chromosome 7 , and gain of chromosome 20 occurred three times. Moreover, translocations involving the $\mathrm{q}$ arms of chromosomes 4 and 18, and translocations involving chromosomes 2, 3, and 16 were noted in at least two of the chemoresistant cell lines (Table III).

\section{Discussion}

We have conducted a comprehensive molecular cytogenetic characterization of 10 widely used BL-derived B cell lines using SKY and CGH. QF-PCR analysis was performed to exclude cross-contamination of the cell lines prior to karyotyping, and to ascertain the common origin of the Mutu cell
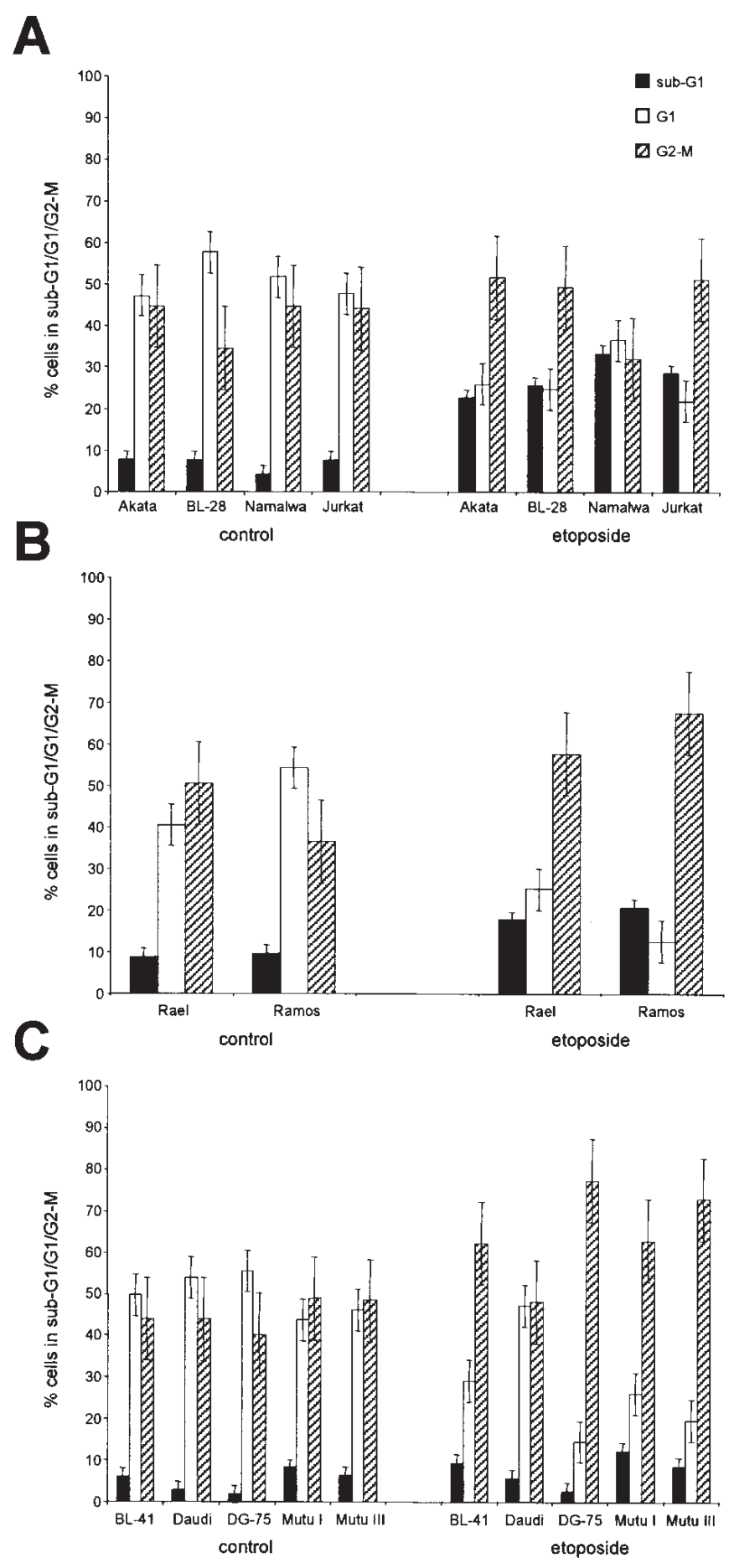

Figure 4. Apoptyping of BL-derived cell lines. Quantification of apoptosis/ cell-cycle responses of sensitive (A), intermediately sensitive (B), and (C) resistant BL cell lines. The Jurkat $\mathrm{T}$ cell line was included as a positive control. Data are derived from DNA histograms of propidium iodide-stained cells. In sensitive cell lines, a hypodiploid (sub-G1) peak emerges upon treatment, indicative of apoptosis-specific DNA fragmentation. Cell-cycle arrest is reflected as an accumulation of cells in the G1 or G2-M phase of the cell cycle (consult text for details). The percentage of cells in the sub-G1 (black bars), G1 (white bars), and G2-M phases (cross-hatched bars) of the cell cycle in the presence or absence of etoposide $(6 \mu \mathrm{g} / \mathrm{ml})$ is depicted for each cell line. Data are shown as mean \pm SD $(n=3-6)$. For comparison, the p53 status of each cell line is shown in Table V.

lines. In addition, functional assessment (apoptyping) served to classify these cell lines as sensitive or resistant to the chemotherapeutic drug, etoposide, and allowed us to identify specific 
patterns of chromosomal aberrations in the chemoresistant cell lines. Overall, our results suggest an unexpected degree of karyotypic complexity among BL cell lines. A number of previously hidden aberrations were detected, including balanced and unbalanced translocations, deletions, duplications, and insertions. The origins of all complex rearrangements were resolved, thus testifying to the usefulness of the molecular cytogenetic techniques utilized herein.

Spectral karyotyping (SKY) has been shown to reveal hidden structural aberrations in hematological malignancies (31). Similarly, our previous SKY analyses of childhood acute lymphoblastic leukemia (ALL) samples have disclosed numerous abnormalities not identified by G-banding, and served to provide prognostically important information $(32,33)$. The cell lines included herein were established before the advent of molecular cytogenetics, and the previous karyotypes were based on chromosome banding methods. The current study has thus served to refine and resolve the karyotypes of these cell lines. Moreover, we identified corresponding abnormalities in our panel of BL-derived cell lines and primary BL tumors, suggesting that these cell lines represent a faithful model of BL, at least from a cytogenetic point of view. Similarly, in their study of the so-called NCI-60 panel of cancer cell lines, Roschke et al (34) showed that the spectrum of aberrations in each cell line correlated with the spectrum of aberrations seen in the corresponding primary tumor. On the other hand, recent studies of the NCI-60 cell lines have shown that the expression of tumor- and tissue-specific genes can vary between cell lines originating from the same type of tumor (35). Future gene expression profiling studies of the panel of BL cell lines presented herein may serve to complement the current cytogenetic findings.

Previous studies have indicated that cancer cell lines may remain karyotypically stable under steady-state conditions, despite decades of continuous cultivation $(13,30)$. However, when a change in culture conditions is introduced, such as a selection pressure toward certain phenotypic features (e.g. drug resistance), it may cause changes in the cytogenetic constitution of a cell line $(36,37)$. Our characterization of the Mutu I and Mutu III cell lines provides evidence that variations in the expression of EBV genes also may exert a dramatic influence on the degree and complexity of karyotypic aberrations. Kiss et al (38) have shown that re-introduction of EBV into an EBV-negative subline of the BL cell line, Akata, activates the expression of $T C L-1$, a cellular proto-oncogene, and they suggested that high expression of $T C L-1$ is necessary for the development of the BL phenotype. Further exploration of the chromosomal abnormalities in the Mutu III cell line, and a detailed comparison between Mutu I and Mutu III, may provide additional clues regarding the contribution of EBV to the growth and/or tumorigenicity of EBV-positive BL.

Chromosomal translocations involving c-myc, the genetic hallmark of BL, were among the earliest molecular alterations found in human cancer $(39,40)$. Since then, only a few secondary lesions have been identified in BL, including anomalies involving chromosome $17 \mathrm{p}$, correlating with deletions and mutations of tumor suppressor gene p53 $(41,42)$, and mutations or translocations of the BCL6 gene located on chromosome $3 q(43,44)$. Alterations involving the long arm of chromosome 1 were also reported in several cases of BL and 'Burkitt-like' ALL $(45,46)$, and Lenoir and colleagues found that aberrations of chromosome 1 were more frequent in BL cell lines with high and moderate tumorigenicity in nude mice (47). In line with these findings, recent molecular cytogenetic characterization of two cell lines derived from sporadic BL (CA46 and ST486) disclosed that only the highly tumorigenic CA46 cell line harbored a 1q23-q24 duplication (48). In the current survey, only Namalwa, the most complex of the 10 cell lines, displayed aberrations of chromosome 1q (gain of genomic material at 1q12-q25). On the other hand, we observed a spectrum of other recurring aberrations, including trisomies of chromosomes 7 and 20, and translocations involving chromosomes 3, 13, and 17. Moreover, common regions of copy number changes included gains at 2p, 3q, 13q, and 16q, and losses at 3p, 4q, and 17p. All of these aberrations have been observed previously in cancer cell lines or primary tumors. For instance, Mehra et al (49) have reported on the cytogenetic features of $10 \mathrm{NHL}$ cell lines, and noted frequent gains on $3 q, 7 p$ and $7 q, 13 q$, and loss of genomic material on $17 \mathrm{p}$. Furthermore, in a recent study of BL and BL-like lymphomas in children, chromosomal abnormalities that involved 13q32 and partial duplication of $1 \mathrm{q}$ were shown to be associated with poor prognosis (50).

Resistance to apoptosis is one of the cardinal features of cancer cells, and contributes to their chemoresistance (18). Around half of all human tumors carry mutations in the tumor suppressor, p53, and tumors that express wild-type p53 frequently display other alterations in the p53 pathway that ablate the p53 response (51). For instance, recent observations suggest that deregulated BCL6 expression may functionally inactivate p53, even in the absence of p53 mutations (52). Moreover, metastatic melanomas often show silencing of Apaf-1, an adaptor molecule that acts together with cytochrome $\mathrm{c}$ and pro-caspase-9 to mediate p53-dependent apoptosis (53). Our recent studies of the Raji BL cell line have revealed a novel mechanism of chemoresistance: plasma membrane sequestration of Apaf-1, also resulting in defective cytochrome c-dependent activation of caspases (54). Of note, 8 of the $10 \mathrm{BL}$ cell lines included in the present study were previously reported to harbor mutations in p53. Furthermore, as shown herein, 3 of these cell lines displayed deletions of $17 \mathrm{p}$, rendering the mutant copy of p53 hemizygous. A majority of the BL cell lines tested were resistant to the chemotherapeutic drug, etoposide (55; and the present study); moreover, several cell lines displayed cell-cycle deregulation, a common finding in high-growth fraction lymphomas (56). However, since not all of the BL cell lines express mutant p53, and not all cell lines are defective for Apaf-1 (54), other underlying defects may determine the outcome of treatment. Indeed, we observed a recurrence of specific chromosomal abnormalities in the chemoresistant cell lines. Additional studies are needed to determine the putative role of these anomalies in the unresponsiveness to chemotherapeutic agents. Interestingly, at the time of writing of the present report, Roschke et al (57) provided evidence that the karyotypic 'state' of a cancer cell line is a potential determinant for anticancer drug discovery targeting the most aggressive and intractable tumors.

In conclusion, our studies have provided a detailed cytogenetic overview of 10 human BL-derived cell lines. Properly 
authenticated cancer cell lines are an indispensable research tool and have yielded seminal insights into the biology of human cancer $(58,59)$; a thorough characterization of cell lines should thus be a priority task for the laboratories which use them. Detailed information on chromosomal abnormalities in hematological malignancies is important because specific aberrations have a strong prognostic value $(60,61)$. Moreover, precise analysis of certain rearrangements is a crucial step in the identification of genes that play a role in the pathogenesis of human cancer (62). Hence, the cytogenetic data presented here should serve as a valuable resource in future studies aimed at gene discovery and functional analysis.

\section{Acknowledgements}

We wish to thank Anita Westman and Xiangning Zhang, Microbiology and Tumor Biology Center, Karolinska Institutet, for assistance in procuring the BL cell lines, and to Kristina Lagerstedt, Helena Malmgren, Sigrid Sahlen, and Irene White, Center for Molecular Medicine, Karolinska University Hospital, for their skillful technical assistance and the generous provision of reagents. This study was supported by the Jenny Nordqvist Foundation, the Märta and Gunnar Philipson Foundation, the Swedish Children's Cancer Foundation, the Swedish Cancer Foundation, and the Swedish Research Council.

\section{References}

1. Blum KA, Lozanski G and Byrd JC: Adult Burkitt leukemia and lymphoma. Blood 104: 3009-3020, 2004.

2. Hecht JL and Aster JC: Molecular biology of Burkitt's lymphoma. J Clin Oncol 18: 3707-3721, 2000.

3. Klein G and Klein E: Evolution of tumours and the impact of molecular oncology. Nature 315: 190-195, 1985.

4. Pulvertaft RJV: Cytology of Burkitt's tumour (African lymphoma). Lancet 39: 238-240, 1964.

5. Epstein MA, Achong BG and Barr YM: Virus particles in cultured lymphoblasts from Burkitt's lymphoma. Lancet 15: 702-703, 1964.

6. Young LS and Rickinson AB: Epstein-Barr virus: 40 years on. Nat Rev Cancer 4: 757-768, 2004.

7. Mitelman F, Mertens F and Johansson B: A breakpoint map of recurrent chromosomal rearrangements in human neoplasia. Nat Genet 15: 417-474, 1997.

8. Kallioniemi A, Kallioniemi OP, Sudar D, Rutovitz D, Gray JW, Waldman $\mathrm{F}$ and Pinkel D: Comparative genomic hybridization for molecular cytogenetic analysis of solid tumors. Science 258: 818-821, 1992.

9. Schröck E, Du Manoir S, Veldman T, Schoell B, Wienberg J, Ferguson-Smith MA, Ning Y, Ledbetter DH, Bar-Am I, Soenksen D, Garini Y and Ried T: Multicolor spectral karyotyping of human chromosomes. Science 273: 494-497, 1996.

10. Caspersson T, Zech L and Johansson C: Differential binding of alkylating fluorochromes in human chromosomes. Exp Cell Res 60: 315-319, 1970.

11. Manolov G and Manolova Y: Marker band in one chromosome 14 from Burkitt lymphomas. Nature 237: 33-34, 1972.

12. Zech L, Haglund U, Nilsson K and Klein G: Characteristic chromosomal abnormalities in biopsies and lymphoid-cell lines from patients with Burkitt and non-Burkitt lymphomas. Int J Cancer 17: 47-56, 1976.

13. Karpova MB, Schoumans J, Ernberg I, Henter J-I, Nordenskjöld M and Fadeel B: Raji revisited: cytogenetics of the original Burkitt's lymphoma cell line. Leukemia 19: 159-161, 2005.

14. Hanahan D and Weinberg RA: The hallmarks of cancer. Cell 100: 57-70, 2000.

15. Vogelstein B and Kinzler KW: Cancer genes and the pathways they control. Nat Med 10: 789-799, 2004.

16. Vaux DL, Cory S and Adams JM: Bcl-2 gene promotes haemopoietic cell survival and cooperates with c-myc to immortalize pre-B cells. Nature 335: 440-442, 1988.
17. Strasser A, Harris AW, Bath ML and Cory S: Novel primitive lymphoid tumours induced in transgenic mice by cooperation between $m y c$ and $b c l-2$. Nature 348: 331-333, 1990.

18. Kaufmann SH and Vaux DL: Alterations in the apoptotic machinery and their potential role in anticancer drug resistance. Oncogene 22: 7414-7430, 2003.

19. Szeles A, Falk KI, Imreh S and Klein G: Visualization of alternative Epstein-Barr virus expression programs by fluorescent in situ hybridization at the cell level. J Virol 73: 5064-5069, 1999.

20. Pertl B, Yau SC, Sherlock J, Davies AF, Mathew CG and Adinolfi M: Rapid molecular method for prenatal detection of Down's syndrome. Lancet 343: 1197-1198, 1994.

21. Adinolfi M, Sherlock J and Pertl B: Rapid detection of selected aneuploidies by quantitative fluorescent PCR. Bioessays 17: 661-664, 1995.

22. Mitelman F (ed): ISCN. An international system for human cytogenetic nomenclature. Karger, Basel, 1995.

23. Schoumans J, Nielsen K, Jeppesen I, Anderlid, BM, Blennow E, Brondum-Nielsen K and Nordenskjöld M: A comparison of different metaphase CGH methods for the detection of cryptic chromosome aberrations of defined size. Eur J Hum Genet 12: 447-454, 2004.

24. Nicoletti I, Migliorati G, Pagliacci MC, Grignani F and Riccardi C: A rapid and simple method for measuring thymocyte apoptosis by propidium iodide staining and flow cytometry. J Immunol Methods 139: 271-279, 1991.

25. Hulten MA, Dhanjal S and Pertl B: Rapid and simple prenatal diagnosis of common chromosome disorders: advantages and disadvantages of the molecular methods FISH and QF-PCR. Reproduction 126: 279-297, 2003.

26. Drexler HG, Dirks WG, Matsuo Y and MacLeod RA: False leukemia-lymphoma cell lines: an update on over 500 cell lines. Leukemia 17: 416-426, 2003.

27. Gregory CD, Rowe M and Rickinson AB: Different EpsteinBarr virus-B cell interactions in phenotypically distinct clones of a Burkitt's lymphoma cell line. J Gen Virol 71: 1481-1495, 1990.

28. Gey GO, Coffman WD and Kubicek MT: Tissue culture studies of the proliferative capacity of cervical carcinoma and normal epithelium. Cancer Res 12: 264-265, 1952.

29. Pulvertaft RJV: A study of malignant tumours in Nigeria by short-term tissue culture. J Clin Pathol 18: 261-273, 1965.

30. Macville M, Schröck E, Padilla-Nash H, Keck C, Ghadimi BM, Zimonjic D, Popescu N and Ried T: Comprehensive and definitive molecular cytogenetic characterization of HeLa cells by spectral karyotyping. Cancer Res 59: 141-150, 1999.

31. Veldman T, Vignon C, Schröck E, Rowley JD and Ried T: Hidden chromosome abnormalities in haematological malignancies detected by multicolour spectral karyotyping. Nat Genet 15: 406-410, 1997.

32. Nordgren A, Schoumans J, Söderhall S, Nordenskjöld M and Blennow E: Interphase fluorescence in situ hybridization and spectral karyotyping reveals hidden genetic aberrations in children with acute lymphoblastic leukaemia and a normal banded karyotype. Br J Haematol 114: 786-793, 2001.

33. Nordgren A, Heyman M, Sahlen S, Schoumans J, Söderhall S, Nordenskjöld $M$ and Blennow E: Spectral karyotyping and interphase FISH reveal abnormalities not detected by conventional G-banding. Implications for treatment stratification of childhood acute lymphoblastic leukaemia: detailed analysis of 70 cases. Eur J Haematol 68: 31-41, 2002.

34. Roschke AV, Tonon G, Gehlhaus KS, McTyre N, Bussey KJ, Lababidi S, Scudiero DA, Weinstein JN and Kirch I: Karyotypic complexity of the NCI-60 drug-screening panel. Cancer Res 63: 8634-8647, 2003.

35. Sandberg R and Ernberg I: Assessment of tumor characteristic gene expression in cell lines using a tissue similarity index (TSI). Proc Natl Acad Sci USA 102: 2052-2057, 2005.

36. Knutsen T, Rao VK, Ried T, Mickley L, Schneider E, Miyake K, Ghadimi BM, Padilla-Nash H, Pack S, Greenberger L, Cowan K, Dean M, Fojo T and Bates S: Amplification of 4q21-q22 and the MXR gene in independently derived mitoxantrone-resistant cell lines. Genes Chromosomes Cancer 27: 110-116, 2000.

37. Bylund L, Kytölä S, Lui WO, Larsson C and Weber G: Analysis of the cytogenetic stability of the human embryonal kidney cell line 293 by cytogenetic and STR profiling approaches. Cytogenet Genome Res 106: 28-32, 2004.

38. Kiss C, Nishikawa J, Takada K, Trivedi P, Klein G and Szekely L: $\mathrm{T}$ cell leukemia I oncogene expression depends on the presence of Epstein-Barr virus in the virus-carrying Burkitt lymphoma lines. Proc Natl Acad Sci USA 100: 4813-4818, 2003. 
39. Dalla-Favera R, Bregni M, Erikson J, Patterson D, Gallo RC and Croce CM: Human c-myc onc gene is located on the region of chromosome 8 that is translocated in Burkitt lymphoma cells. Proc Natl Acad Sci USA 79: 7824-7827, 1982.

40. Taub R, Kirsch I, Morton C, Lenoir G, Swan D, Tronick S, Aaronson S and Leder P: Translocation of the c-myc gene into the immunoglobulin heavy chain locus in human Burkitt lymphoma and murine plasmacytoma cells. Proc Natl Acad Sci USA 79: 7837-7841, 1982.

41. Farrell PJ, Allan GJ, Shanahan F, Vousden KH and Crook T: p53 is frequently mutated in Burkitt's lymphoma cell lines. EMBO J 10: 2879-2887, 1991 .

42. Gaidano G, Ballerini P, Gong JZ, Inghirami G, Neri A, Newcomb EW, Magrath IT, Knowles DM and Dalla-Favera R: p53 mutations in human lymphoid malignancies: association with Burkitt lymphoma and chronic lymphocytic leukemia. Proc Natl Acad Sci USA 88: 5413-5417, 1991.

43. Baron BW, Nucifora G, McCabe N, Espinosa R, Le Beau MM and McKeithan TW: Identification of the gene associated with the recurring chromosomal translocations $\mathrm{t}(3 ; 14)(\mathrm{q} 27 ; \mathrm{q} 32)$ and $\mathrm{t}(3 ; 22)(\mathrm{q} 27 ; \mathrm{q} 11)$ in B cell lymphomas. Proc Natl Acad Sci USA 90: 5262-5266, 1993.

44. Capello D, Carbone A, Pastore C, Gloghini A, Saglio G and Gaidano G: Point mutations of the BCL-6 gene in Burkitt's lymphoma. Br J Haematol 99: 168-170, 1997.

45. Douglass EC, Magrath IT, Lee EC and Whang-Peng J: Cytogenetic studies in non-African Burkitt lymphoma. Blood 55: $148-155,1980$.

46. Kornblau SM, Goodacre A and Cabanillas F: Chromosomal abnormalities in adult non-endemic Burkitt's lymphoma and leukemia: 22 new reports and a review of 148 cases from the literature. Hematol Oncol 9: 63-78, 1991.

47. Gurtsevitch VE, O'Conor GT and Lenoir GM: Burkitt's lymphoma cell lines reveal different degrees of tumorigenicity in nude mice. Int J Cancer 41: 87-95, 1988.

48. Zimonjic DB, Keck-Waggoner C and Popescu NC: Novel genomic imbalances and chromosome translocations involving c-myc gene in Burkitt's lymphoma. Leukemia 15: 1582-1588, 2001.

49. Mehra S, Messner H, Minden M and Chaganti RSK: Molecular cytogenetic characterization of non-Hodgkin lymphoma cell lines. Genes Chromosomes Cancer 33: 225-234, 2002.

50. Lones MA, Sanger WG, Le Beau MM, Heerema NA, Sposto R, Perkins SL, Buckley J, Kadin ME, Kjeldsberg CR, Meadows A, Siegel S, Finlay J, Bergeron S and Cairo MS: Chromosome abnormalities may correlate with prognosis in Burkitt/Burkittlike lymphomas of children and adolescents. J Pediatr Haematol Oncol 26: 169-178, 2004.

51. Lowe SW, Cepero E and Evan G: Intrinsic tumour suppression. Nature 432: 307-315, 2004.

52. Phan RT and Dalla-Favera R: The BCL6 proto-oncogene suppresses p53 expression in germinal-centre B cells. Nature 432: 635-639, 2004.

53. Soengas MS, Capodieci P, Polsky D, Mora J, Esteller M, OpitzAraya X, McCombie R, Herman JG, Gerald WL, Lazebnik YA, Cordon-Cardo C and Lowe SW: Inactivation of the apoptosis effector Apaf-1 in malignant melanoma. Nature 409: 207-211, 2001.

54. Sun Y, Orrenius S, Pervaiz S and Fadeel B: Plasma membrane sequestration of apoptotic protease-activating factor-1 in human B lymphoma cells: a novel mechanism of chemoresistance. Blood 105: 4070-4077, 2005.

55. Karpova MB, Sanmun D, Henter J-I, Smirnov AF and Fadeel B: Betulinic acid, a natural cytotoxic agent, fails to trigger apoptosis in human Burkitt's lymphoma-derived B-cell lines. Int J Cancer 118: 246-252, 2006.

56. Sanchez-Beato M, Sanchez-Aguilera A and Piris MA: Cell cycle deregulation in B-cell lymphomas. Blood 101: 1220-1235, 2003.
57. Roschke AV, Lababidi S, Tonon G, Gehlhaus KS, Bussey K, Weinstein JN and Kirsch IR: Karyotypic 'state' as a potential determinant for anticancer drug discovery. Proc Natl Acad Sci USA 102: 2964-2969, 2005.

58. Drexler HG and Minowada J: History and classification of human leukemia-lymphoma cell lines. Leuk Lymphoma 31: 305-316, 1998.

59. Masters JR: Human cancer cell lines: fact and fantasy. Nat Rev Mol Cell Biol 1: 233-236, 2000.

60. Dohner H, Stilgenbauer S, James MR, Benner A, Weilguni T, Bentz M, Fischer K, Hunstein W and Lichter P: 11q deletions identify a new subset of B-cell chronic lymphocytic leukemia characterized by extensive nodal involvement and inferior prognosis. Blood 89: 2516-2522, 1997.

61. Grimwade D, Walker H, Oliver F, Wheatley K, Harrison C, Harrison G, Rees J, Hann I, Stevens R, Burnett A and Goldstone A, on behalf of the Medical Research Council Adult and Children's Leukaemia Working Parties: The importance of diagnostic cytogenetics on outcome in AML: analysis of 1,612 patients entered into the MRC AML 10 trial. Blood 92: 2322-2333, 1998 .

62. Mitelman F: Recurrent chromosome aberrations in cancer. Mutat Res 462: 247-253, 2000.

63. Takada K, Horinouchi K, Ono Y, Aya T, Osato T, Takahashi M and Hayasaka S: An Epstein-Barr virus-producer line Akata: establishment of the cell line and analysis of viral DNA. Virus Genes 5: 147-156, 1991 .

64. Lenoir GM, Preudhomme JL, Bernheim A and Berger R: Correlation between immunoglobulin light chain expression and variant translocation in Burkitt's lymphoma. Nature 298: 474-476, 1982.

65. Klein E, Klein G, Nadkarni JS, Nadkarni JJ, Wigzell H and Clifford P: Surface IgM-kappa specificity on a Burkitt lymphoma cell in vivo and in derived culture lines. Cancer Res 28: 1300-1310, 1968.

66. Ben-Bassat H, Goldblum N, Mitrani S, Goldblum T, Yoffey JM, Cohen MM, Bentwich Z, Ramot B, Klein E and Klein G: Establishment in continuous culture of a new type of lymphocyte from a 'Burkitt-like' malignant lymphoma (line D.G.-75). Int J Cancer 19: 27-33, 1977.

67. Nadkarni JS, Nadkarni JJ, Clifford P, Manolov G, Fenyö EM and Klein E: Characteristics of new cell lines derived from Burkitt lymphomas. Cancer 23: 64-79, 1969.

68. Klein G, Dombos L and Gothoskar B: Sensitivity of EpsteinBarr virus (EBV) producer and non-producer human lymphoblastoid cell lines to superinfection with EB-virus. Int J Cancer 15: 44-57, 1972.

69. Klein G, Lindahl T, Jondal M, Leibold W, Menezes J, Nilsson K and Sundström C: Continuous lymphoid cell lines with characteristics of B cells (bone marrow-derived), lacking the Epstein-Barr virus genome and derived from three human lymphomas. Proc Natl Acad Sci USA 71: 3283-3286, 1974.

70. Wiman KG, Magnusson KP, Ramqvist T and Klein G: Mutant p53 detected in a majority of Burkitt lymphoma cell lines by monoclonal antibody Pab240. Oncogene 6: 1633-1639, 1991.

71. Ramqvist T, Magnusson KP, Wang Y, Szekely L, Klein G and Wiman KG: Wild-type p53 induces apoptosis in a Burkitt lymphoma $(\mathrm{BL})$ line that carries mutant p53. Oncogene 8: 1495-1500, 1993

72. Berger R and Bernheim A: Cytogenetics of Burkitt's lymphomaleukemia: a review. IACR Sci Publ 60: 65-80, 1985.

73. Drexler HG, Dirks W, MacLeod RAF, Quentmeier H, Steube KG and Uphoff CC (eds): Catalogue of Human and Animal Cell Lines. DSMZ, Braunschweig, 2001.

74. Steel CM, Morten JEN and Foster E: The cytogenetics of human B lymphoid malignancy: studies in Burkitt's lymphoma and Epstein-Barr virus-transformed lymphoblastoid cell lines. IARC Sci Publ 60: 265-292, 1985. 